National Science Foundation

\section{Engineering lobby wins token}

\section{Washington}

A LONG-STANDING campaign by Representative George Brown (Democrat, California) to force the National Science Foundation (NSF) to give greater attention to engineering was symbolically endorsed by the House of Representatives Science and Technology Committee late last month when it voted to amend the NSF charter to give explicit recognition to the agency's role in supporting engineering research. The move has revived an old debate over NSF's role and concern that science may suffer from any deviation from what critics such as Dr Frank Press, president of the National Academy of Sciences, call the "fundamental mission" for which the agency was created.

The committee's action, however, according to a committee staff member, in fact does little more than acknowledge the new facts of recent years - NSF's budget for engineering has grown from $\$ 93$ million in 1982 to $\$ 147$ million in President Reagan's 1985 budget request.

Brown's original proposal would have taken the symbolism one step further by changing the name of the foundation to the National Science and Engineering Foundation, but objections over the cost of reprinting stationery seemed to carry the day.
The Science and Technology Committee also recently decided to go one better than the administration by voting to triple the $\$ 20$ million that the administration had allotted to NSF for a new programme in the area of supercomputers. The committee was strongly influenced by testimony from researchers and by an internal working group study presented last summer to the National Science Board (the governing body of NSF) that called for hundreds of millions of dollars to be spent on establishing supercomputer centres around the country to support academic research. Research supercomputers are now confined to the weapons laboratories, some private industry and two special-purpose federal facilities, one for atmospheric research and one for magnetic fusion computing. The Reagan Administration plan stops short of purchasing new machines; the $\$ 20$ million would pay for computer time and access costs on existing machines. The House committee would leave it to an NSF advisory committee on supercomputing to decide just how the extra $\$ 40$ million would be spent, although it specifically encouraged acquisition of new machines, establishment of a national network and support for local access equipment and software development.

Stephen Budiansky

\title{
Australia mounts defence
}

\section{Canberra}

AUSTRALIA is solid on Unesco (the United Nations Educational, Scientific and Cultural Organization), to judge from what the government and its ambassador to Unesco, former prime minister Mr E.G. (Gough) Whitlam have been saying. Indeed, the Australian National Commission for Unesco has urged the government to persuade the United States to reverse its stated intention of withdrawing from Unesco, deploring US intellectual isolation at a critical time in the search for world peace.

Elements of the Australian scientific community attach great value to many Unesco programmes, notably in the fields of hydrology, oceanography and ecology. Australia participates in several Unesco regional networks, which are seen as useful instruments of international cooperation, especially in Asia and the Pacific.

Mr Whitlam spelled out his own position here on 21 March, saying that while Australia supported the need for the press to be free, Unesco's work programme for 1984-85 on the New World Information and Communication Order (NWICO) had been accepted at last year's conference without dissent. Yet the programme is cited as one of the principal reasons for the pro- posed US withdrawal. In any case, $\mathrm{Mr}$ Whitlam said, the privately-owned press is not as accurate as it should be.

The ambassador claimed that nothing in his own public utterances could be construed as an attack on the United States. In a partly-leaked version of a despatch to the Australian Government from his office in Paris, however, he is reported to have accused President Ronald Reagan of withdrawing from the organization as a sop to the "rabid right".

Mr Whitlam is further reported to have described Mr Amadou-Mahtar M'Bow, director-general of Unesco, as an outstandingly well-informed, competent and eloquent person: thoroughly alert, diligent and temperate. He recommended that the Australian Government invite Mr M'Bow to make an official visit to Australia, and defended the much-maligned Unesco staff, if defend is the right word, by allowing that they did not compare badly with Australian politicians, public scrvants and academics of his acquaintance.

One of Mr Whitlam's complaints was that the press had not mentioned that Unesco's books are normally certified by the British auditor-general. The US investigation of Unesco will begin this month.

Jeffrey Sellar
Fishery stocks

\section{Group leaps to aid salmon}

THE North Atlantic Salmon Conservation Organization (NASCO) is now a going concern. But the inaugural meeting in Edinburgh earlier this year served simply to emphasize yet again that the migratory salmon poses the most difficult of all fisheries problems. The aim of NASCO is the conservation and also enhancement of salmon stocks in the North Atlantic. Its members are Canada, the United States, Denmark (in respect of the Faroes and including Greenland), Iceland, Norway and the European Economic Community (EEC) on behalf of interested member states - the United Kingdom, Ireland, Denmark and France.

The UN Conference on the Law of the Sea has laid down the principle that "states in whose rivers anadromous stocks originate shall have the primary interest in and responsibility for such stocks"' and advocates a 200 -mile limit, but the treaty is not yet in force. Meanwhile, EEC has prohibited salmon fishing in Community

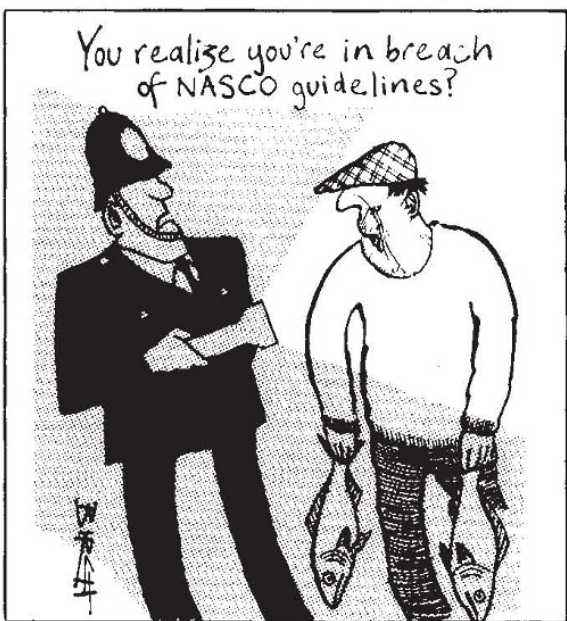

waters beyond a 12-mile limit and sets quotas $(2,000$ tonnes in 1984) for Danish and West German fishing in the feeding areas off Greenland and in the Baltic. The Faroes have a separate quota agreement with EEC. Figures published by the International Council for the Exploration of the Sea (ICES) show a growth of Faroes/Danish catch in 1979-81 from zero to 1,025 tonnes.

NASCO will use ICES as a scientific advisory body and will try to formulate and rationalize international agreements to balance the needs of the international fishing community with those of individual countries.

Salmon frequently play a key role in the economies of rural areas poor in resources. Freshwater fishing is the largest participant field sport in the United Kingdom and France, for example. The Swiss are attempting to restock the Rhine with Swedish salmon. Countries of origin invest considerable sums in the conservation of 